e-ISSN: 2721-3013, p-ISSN: 2721-3005

DOI: https://doi.org/10.38035/jafm.v1i4

Received: 6 Agust 2020, Revised: 21 Agust 2020, Publish: 14 September 2020 https://creativecommons.org/licenses/by/4.0/

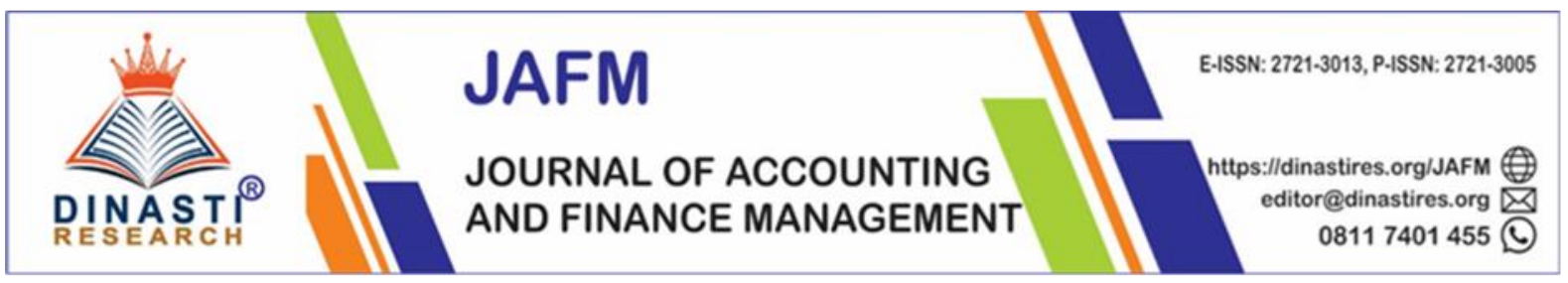

\title{
Measuring Stock Prices Through Earning per Share, Profitability, Solvability and Corporate Governance as Moderation Variables (Case Study on Manufacturing Companies Listed on the Indonesia Stock Exchange (IDX) 2015-2019)
}

\author{
Mondra Neldi ${ }^{*}$, Nandan Limakrisna ${ }^{2}$ \\ 1),2) Universitas Putra Indonesia YPTK Padang, Indonesia, mondraneldi@gmail.com \\ *Corresponding author: Mondra Neldi ${ }^{1}$
}

\begin{abstract}
This study aims to examine how much influence Earning Per Share, Profitability, and Solvability with Corporate Governance as a moderating variable. The population of this study was 71 companies listed on the Indonesia Stock Exchange (IDX) with a sample of 30 companies during 2013-2017. This study uses purposive sampling. The data analysis technique used in this study is multiple linear regression analysis.From this study the conclusions are as follows: Earning Per Share variable shows the results that have a positive and significant effect on stock prices, Profitability and Solvability shows no effect on Stock Prices, Earning Per Share which is moderated by Corporate Governance, Profitability moderated by Corporate Governance and Solvability moderated by Corporate Governance shows results that have no significant effect on stock prices. In further research, it is expected to be able to add independent variables to be able to explain what is the influence of the dependent variable, namely stock prices, and add all public companies to become research and replace the proxy of each variable to get better research results.
\end{abstract}

Keywords: Stock Prices, Earning Per Share, Profitability, Solvability, Corporate Governance

\section{INTRODUCTION}

Developments to invest in financial instruments that became a way for the owners of capital to develop their funds. Financial investment has advantages over the physical investments/real in terms of liquidity and ease of investing. One alternative investment developed at this time, namely mutual funds. Mutual fund is a container for collecting funds from the public for the next placed in a portfolio (Agussalim et al., 2017)

The current phenomenon of the development of the capital market in Indonesia has not had a significant impact on the Indonesian economy. Many factors cause this condition, such as low public interest in investing, people who lack understanding of the capital market, and the still few issuers listed on the stock exchange. 
The factors come from within country can be formed as macroeconomic factors such as, the change of exchange rate, level of interest rate, inflation, and gross domestic product. Whereas, the factors come from foreign countries are either globally integrated capital market or the economic situation in a country (Desfiandi et al., 2017)

One sign of investor confidence about an issuer whose value is the stock price. Therefore, in order not to experience losses, investors must always monitor fluctuations in share prices and the factors that can affect stock prices in order to determine when to sell or buy shares. The movement of the Composite Stock Price Index (IHSG) experienced a weakening as in the PANI company (Pratama Abadi Nusa Industri Tbk) so that it suppressed the JCI. The decline has a negative impact on the domestic stock market. This is due to when the rupiah exchange rate weakened. Investors will avoid import-oriented companies, because the high US dollar will affect the costs to be incurred by the company and will impact the profits obtained by the company.

EPS (Earning Per Share) is one of the accounting information that shows the amount of net profit per share that the company can generate. "The EPS value will be compared with the value obtained in the same quarter last year, thus describing the company's profits. The results of the comparison can be used to predict the increase / decrease in stock prices .

The profitability ratio used in this study is Return On Asset. According to (Adipalpuga I G N Sudangga dan Suarjaya Anak Agung Gede, 2016) state that Return On Assets is the ratio of net income to total assets that measures the return on total assets after interest and taxes. If the Return on Assets of a company increases, it means that the company's profitability will increase, of course, it will have an impact on increasing the profitability enjoyed by investors. This will increase the attractiveness of investors, so that the demand for the company's shares will increase and will also increase the share price (Kasmir, 2014).

Solvability is the ratio of a company's ability to meet its financial obligations. A company is said to be solvable if the company has sufficient assets or assets to pay off all its debts (Suad Husnan, 2015)

The role of company management is needed to stabilize company performance. Corporate governance is the concept of a series of mechanisms to direct and control a company so that the company's operations run according to investors' expectations. Corporate governance can be defined as the structures, systems and processes used by company management as a way to add value to a company in an orderly manner in the long term.

Based on the introduction above, the problem can be formulated as follows, how is it affected:

1. Earning Per Share Against share price

2. Profitability against share price

3. Solvability Against Harha shares

4. Earning Per Share moderated by Corporate Governance on share prices

5. Profitability which is moderated by Corporate Governance towards Prices

6. Solvability moderated by Corporate Governance on share prices

in manufacturing companies listed on the Indonesia Stock Exchange in 2015-2019.

\section{LITERATURE REVIEW \\ Stock price}

According to (Muhammad Ircham, 2014), stock prices can also be interpreted as prices that are formed from the price of interactions between sellers and buyers of shares against the background of their expectations of company profi. Share price is the price that occurs on the stock exchange at a certain time which is determined by market players and determined by market players and is determined by the demand and supply of the relevant shares in the capital market. 


\section{Earning Per Share}

According to (Irham Fahmi, 2012), Earning Per Share (EPS) is one of the ratios used to analyze stock prices. Earnings per share (EPS) is a form of giving benefits to shareholders from each share they own. EPS is a comparison between net income after tax in the financial year published by the company. In general, it can be explained that EPS is the level of net profit for each share that the company can achieve when running its operations.

\section{Profitability}

According to (Kasmir, 2014), Profitability is the ratio to assess the company's ability to seek profit or profit in a certain period. This ratio also provides a measure of the level of management effectiveness of a company. This is shown by the profit generated from sales and investment income. The point is in using this ratio, it shows the efficiency of the company. According to (Irham Fahmi, 2012), the profitability ratio measures the effectiveness of management as a whole which is shown by the size of the level of profits obtained in relation to sales and investment. The better the profitability ratio, the better it describes the company's high profitability.

\section{Solvability}

According to (Adipalpuga I G N Sudangga dan Suarjaya Anak Agung Gede, 2016), Solvability is the ratio of a company's ability to meet its financial obligations. In this study, the Solvability ratio used is the Dept to Equity Ratio (DER) which is the most frequently used debt ratio. The amount of debt contained in the company's capital structure is important to understand the consideration between risk and profit.

\section{Corporate Governance}

According to (Adrian Sutedi, 2011), Corporate Governance can be defined as a process and structure used by company organs (shareholders / capital owners, commissioners / supervisors and directors) to increase business success and company accountability to realize shareholder value in the long term. long while still paying attention to the interests of other skateholders, based on company legislation and ethical values. According to (Sedarmayanti, 2012) the term "Corporate Governance" was first introduced by Cadbury Committee in 1992 in a report known as Cadbury Report. This report is a defining turning point for corporate governance practices around the world.

\section{Framework}

Based on the theoretical relationship between variables, Earning Per Share, Profitability, and Solvability with Corporate Governance as a moderating variable:

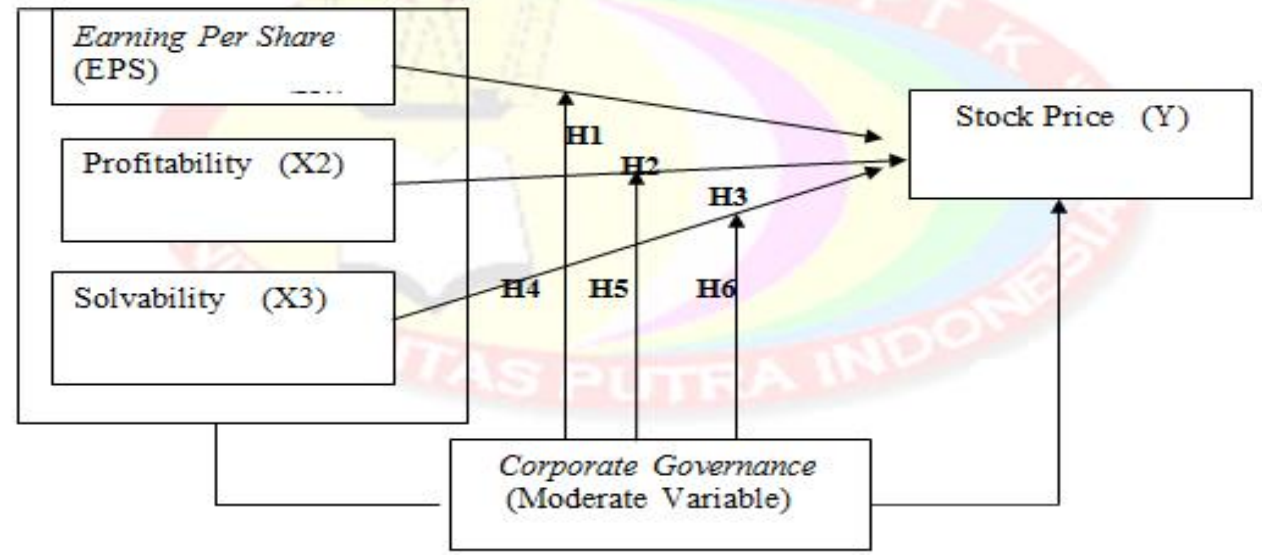

Figure 1. Research Conceptual Framework 


\section{Hypothesis}

Based on the framework described in the previous section, the hypotheses put forward in this study are as follows:

H1: Earning Per Share Affects Stock Prices

H2: Profitability Affects Price

H3: Solvability has an effect on stock prices

H4: Earning Per Share moderated by Corporate Governance has an effect on stock prices

H5: Profitability which is moderated by Corporate Governance has an effect on stock prices

H6: Solvability which is moderated by Corporate Governance has an effect on stock prices

\section{RESEARCH METHOD}

1. Descriptive Statistical Analysis

According to (Sugiyono, 2014) descriptive statistics are statistics that are used to analyze data by describing or describing the data that has been collected as it is without intending to make general conclusions or generalizations.

2. Multiple Regression Analysis

$$
\begin{gathered}
\mathrm{P}=\mathrm{a}+\beta_{1} E P S+\beta_{2} P R O F+\beta_{3} S O L+\beta_{4} E P S^{*} C G+\beta_{5} \\
P R O F^{*} C G+\beta_{6} S O L^{*} C G+\mathrm{e}
\end{gathered}
$$

\section{RESULTS AND DISCUSSION}

\begin{tabular}{|c|c|c|c|c|c|}
\hline \multirow[t]{3}{*}{ Modal } & \multicolumn{2}{|c|}{ Unstandardized Coefficients } & \multirow{3}{*}{$\begin{array}{l}\text { Standardized } \\
\text { Coefficients } \\
\text { Beta }\end{array}$} & \multirow{3}{*}{$\mathrm{t}$} & \multirow{3}{*}{ Sig } \\
\hline & & & & & \\
\hline & $\mathrm{B}$ & Std. Error & & & \\
\hline (Constant) & 6,053 &, 144 & & 42,058 & 000 \\
\hline Eps & ,004 &, 000 & ,727 & 10,921 & 000 \\
\hline 1 Roa &, 320 & ,820 &, 024 & ,390 & ,697 \\
\hline Der &,- 083 & 056 &,- 091 & $-1,493$ & 697 \\
\hline Mod_eps &, 000 &, 004 &,- 004 &,- 043 & ,966 \\
\hline Mod_roa & $-57,001$ & 41,673 &,- 124 & $-1,368$ & 174 \\
\hline Mod_der & $-3,012$ & 2,944 &,- 064 & $-1,023$ & ,308 \\
\hline
\end{tabular}

Table 1. Result of $t$ Test

a. The Effect of Earning Per Share on Stock Prices

It is known that tcount $>$ ttable (10.921> 1.655) with a significant level of 0.000 less than $0.05(0.000<0.05)$, it can be concluded that the variable Earning Per Share partially has a significant effect on stock prices. So that $\mathrm{HO}$ is rejected and $\mathrm{Ha}$ is accepted.

b. Effect of Profitability on stock prices

It is known that tcount <ttable $(0.390<1.655)$ with a significant level of 0.697 greater than $0.05(0.697>0.05)$, it can be concluded that the profitability variable partially has no significant effect on stock prices. So that $\mathrm{H} 0$ is accepted and $\mathrm{Ha}$ is rejected.

c. The Effect of Solvability on Stock Prices

It is known that tcount <ttable $(-1.493<1.655)$ with a significant level of 0.138 greater than $0.05(0.138>0.05)$, so it can be concluded that the Solvability variable partially has no significant effect on stock prices. So that $\mathrm{HO}$ is accepted and Ha is rejected.

d. The influence of Earning Per Share, moderated by corporate governance, on stock prices It is known that tcount <ttable $(-0.043<1.655)$ with a significant level of 0.966 greater than 0.05 (0.966>0.05), it can be concluded that the variable Earning Per Share moderated 
by corporate governance partially has no significant effect on prices. stock. So that $\mathrm{H} 0$ is accepted and $\mathrm{Ha}$ is rejected.

e. The influence of profitability, which is moderated by corporate governance, on stock prices

It is known that tcount <ttable $(-1.368<1.655)$ with a significant level of 0.174 greater than $0.05(0.174>0.05)$, it can be concluded that the partially moderated profitability variable by corporate governance has no significant effect on stock prices. So that HO is accepted and $\mathrm{Ha}$ is rejected.

f. The influence of Solvability which is moderated by corporate governance on stock prices, It is known that tcount <ttable $(-1.023<1.655)$ with a significant level of 0.308 greater than $0.05(0.308>0.05)$, it can be concluded that the Solvability variable moderated by corporate governance partially has no significant effect on stock prices. So that $\mathrm{HO}$ is accepted and $\mathrm{Ha}$ is rejected.

Table 2. Result of $\mathbf{R}^{2}$

Model Summary

\begin{tabular}{ccccc}
\hline Model & $\mathrm{R}$ & $\mathrm{R}$ Square & $\begin{array}{c}\text { Adjusted R } \\
\text { Square }\end{array}$ & $\begin{array}{c}\text { Std. Error of the } \\
\text { Estimate }\end{array}$ \\
\hline 1 &, $778^{\mathrm{a}}$ &, 605 &, 584 &, 90480 \\
\hline
\end{tabular}

a. Predictors: (Constant), ln_km, der, roa, eps

b. Dependent Variable: ln_Stock Price

This shows that there is a strong influence between Earning Per Share, profitability, Solvability, Earning Per Share moderated by corporate governance, profitability moderated by corporate governance, Solvability moderated by corporate governance on the dependent variable stock price of 0.605 or $60.5 \%$ while the remaining $39.5 \%$ is influenced by other variables outside of this study.

\section{Research Hypothesis Testing Results}

Tabel 3. Research Hypothesis Testing Results

\begin{tabular}{clccc}
\hline Hypothesis & \multicolumn{1}{c}{ Statement } & Significant & Comparative & Decision \\
\hline $\mathrm{H}_{1}$ & $\begin{array}{l}\text { It is suspected that Earning Per Share } \\
\text { has a significant effect on stock prices }\end{array}$ & 0,000 & 0,05 & Accepted \\
\hline $\mathrm{H}_{2}$ & $\begin{array}{l}\text { It is suspected that profitability has a } \\
\text { significant effect on stock prices }\end{array}$ & 0,697 & 0,05 & Rejected \\
\hline $\mathrm{H}_{3}$ & $\begin{array}{l}\text { It is suspected that Solvability has a } \\
\text { significant effect on stock prices }\end{array}$ & 0,138 & 0,05 & Rejected \\
\hline $\mathrm{H}_{4}$ & $\begin{array}{l}\text { It is suspected that Earning Per Share } \\
\text { moderated by corporate governance } \\
\text { has a significant effect on stock prices }\end{array}$ & 0,966 & 0,05 & Rejected \\
\hline $\mathrm{H}_{5}$ & $\begin{array}{l}\text { It is suspected that profitability which } \\
\text { is moderated by corporate governance } \\
\text { has a significant effect on stock prices }\end{array}$ & 0,174 & 0,05 & Rejected \\
\hline $\mathrm{H}_{6}$ & $\begin{array}{l}\text { It is suspected that Solvability, which } \\
\text { is moderated by corporate governance, } \\
\text { has a significant effect on stock prices }\end{array}$ & 0,308 & 0,05 & Rejected \\
\hline
\end{tabular}

\section{CONCLUSIONS AND SUGGESTIONS}

\section{Conclusion}

Based on research conducted with the discussion of hypothesis testing entitled Earning Per Share, profitability, and solvency on stock prices moderated by corporate governance. Then some important conclusions can be proposed which are the core answers to the problems discussed in this study, namely: 
a. Partially Earning Per Share has a significant effect on stock prices

b. Partial profitability does not have a significant effect on stock prices

c. Partial solvability has no significant effect on stock prices

d. Earning Per Share, which is partially moderated by corporate governance, has no significant effect on stock prices

e. Profitability which is moderated by corporate governance partially does not have a significant effect on stock prices

f. Solvability which is moderated by corporate governance partially does not have a significant effect on stock prices

\section{Suggestion}

Based on the conclusions of this study, the following suggestions can be made:

a. Further research is expected to be able to add an independent variable that will be able to explain what will be an influence on the dependent variable, namely stock prices.

b. For further research, to conduct research, it is better if you take from all public companies in Indonesia except for manufacturing companies, increase the research time period and replace the proxies used in order to obtain better results. And further research should be able to develop this research to add more variables.

c. The management of the company is expected to pay more attention to the company's performance in order to run well as well as to increase the share price so that more investors will pay attention to investing in the company.

\section{REFERENCES}

Adipalpuga I G N Sudangga dan Suarjaya Anak Agung Gede. (2016). Pengaruh Likuiditas, Solvabilitas, Aktivitas, Profitabilitas, dan penilaian Pasar Terhadap Harga Saham Perusahaan LQ45 di Bursa Efek Indonesia. E- Jurnal Manajemen Unud, 5(12).

Adrian Sutedi. (2011). Good corporate governance. Sinar Garfika.

Agussalim, M., Limakrisna, N., \& Ali, H. (2017). International Journal of Economics and Financial Issues Mutual Funds Performance: Conventional and Sharia Product. International Journal of Economics and Financial Issues.

Desfiandi, A., Desfiandi, A., \& Ali, H. (2017). Composite Stock Price Index (IHSG) Macro

Factor in Investment in Stock (Equity Funds). International Journal of Economics and Financial Issues.

Irham Fahmi. (2012). Manajemen Investasi: Teori Dan Soal Jawaban. salemba empat.

Kasmir. (2014). Analisis Laporan Keuangan. raja grafindo persada.

Muhammad Ircham. (2014). Pengaruh Struktur Modal dan Profitabilitas Terhadap Harga Saham. In Universitas Brawijaya. Universitas Brawijaya.

Sedarmayanti. (2012). good governance \& good corporate governance (3rd ed.). CV Mandar Maju.

Suad Husnan. (2015). Dasar-dasar Teori Portofolio dan Analisis Sekuritas (5th ed.). BPFE. Sugiyono. (2014). Metode Penelitian Pendidikan (Pendekatan Kuantitatif, Kualitatif, dan $R$ \& D). Alfabeta. 